\title{
STUDENT'S PERCEPTION OF THEIR ACADEMICS AND CLINICAL PRACTICE ON GRADUATION FROM DENTAL COLLEGES OF PESHAWAR
}

\author{
Saira Afridi ${ }^{1}$, Jawad Ahmad Kundi ${ }^{1}$, Syed Imran Gillani ${ }^{1}$, Yasir Ibad ${ }^{1}$, Rohail Muhammad ${ }^{1}$, Riaz Gillani $^{1}$, \\ Moiz Raza', Haseeb ${ }^{1}$
}

1. Sardar Begum Dental College

\section{ABSTRACT}

OBJECTIVE:

The objective of the current study was to know the perception of students regarding dental curriculum in clinical practice and academics after their graduation in three dental colleges of Peshawar.

MATERIAL AND METHODS:

It was a cross-sectional study design, carried out at three dental colleges of Peshawar namely Khyber College of Dentistry, Sardar Begum Dental College and Peshawar Dental College. officers were there out of which93 participated in the study. A pilot study was

A total number of 193 house reliability of questionnaire. The study was conducted through a self $\quad$-administered questionnaire. The questionnaire consisted questions about academics and clinical practice.

\section{RESULTS:}

Our sample consisted of 93 subjects. There were $79 \%$ females and $21 \%$ males. The results revealed an overall positive learning experience in undergraduate academics and clinical practice. Over $86 \%$ of the graduates were satisfied with their academics and about $69 \%$ were satisfied with clinical practice. Almost $90 \%$ of the subjects were confident in carrying out specific clinical procedures.

\section{CONCLUSION:}

The major conclusions were that academics and clinical practice was satisfactory to the majority of subjects, although some areas of concern were identified that need improvement.

\section{KEYWORDS:}

Undergraduate medical curriculum, Students perception, dental students

\section{INTRODUCTION}

The term curriculum refers to "all the learning that is planned and guided by the school, whether it

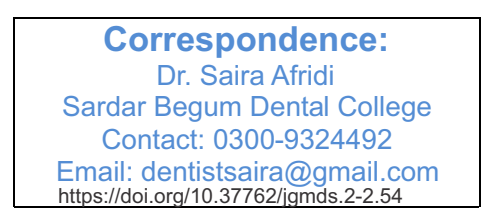
is carried out in groups or individually, inside or outside the school." 1 An inflexible curriculum is stagnant, whereas a good curriculum always restructures itself to the students', community and profession's needs. The dental curriculum is no exception. General needs assessments, needs assessment of targeted learners, feedback from all stakeholders, and planned evaluation of the curriculum are some ways in which curriculum is developed. ${ }^{2,3}$ In health professional education, there are profession specific objectives of training and learning leading to a complete array of competencies which are required to become a technically competent and a sensitive health care professional. Health professionaeducation has undergone a complete transformation in the last quarter of the century. Introduction of competencies in the late $20^{\text {th }}$ century have not only served to provide a framework for development of curricula, but can also be used to assess deficiencies in delivering these curriculum. ${ }^{4}$

Mostly students undergo two stages during their study period. First is the fresh transition from undergraduate to professional college. Second is when they shift from class room to clinical 
environment. At both of these stages students observe the drawbacks and benefits of the dental curriculum. As a result students find their school environment and studies very stressful. 2 The perception of dental students holds a key importance in the development of dental school curriculum. In today's stressful study environment, it is important to keep the student interested and motivated towards their curriculum as clearly this is said to yield better resultsln most institutes the students are neglected while designing the dental school curriculum.

It is suspected that the dental curriculum does not stand up to the expectations of students. The students are interested in having hands on experience rather than the traditional emphasis on memorization. It is speculated that an altered curriculum would increase student's level of interest thereby eventually promoting learning process ${ }^{i}$. There is a need to incorporate a need based curriculum, in which the curriculum development process involves the needs of students, community dental researchers and dental clinicians. ${ }^{2,3}$

Although there are several methods to evaluate a curriculum, taking the students' perspective are of crucial importance. ${ }^{5}$.Students are the keen observers. Giving importance to student's views regarding curriculum may bring fruitful results. ${ }^{6,7}$ With the help of this research we are trying to gain an insight of student's likes and dislikes about their current curriculum.Therefore, our study was conducted to assess the perception of students of academics and clinical practie at the time of graduation in three dental colleges of Peshawar.

\section{MATERIALS AND METHODS}

This cross sectional study was conducted at three dental coll eges of Peshawar namely Khyber College of D entistry (KCD),Sardar Begum Dental College (SBDC) and Peshawar Dental College (PDC) from September 2015 to February 2016.Study population comprised of all the male and female house officers working at KCD, SBDC and PDC.The ethical approval was obtained by the ethical committees of all the dental colleges and formal approval for study was obtained from the heads of the institutes. Written informed consent was also obtained from every study participant. The study was conducted through a self administeredquestionnaire validated among a group of 10 subjects before using it for final survey. The instrument consisted of number of questions related to academics and clinical practice. The domains were student opinions regarding learning experience in undergraduate curriculum, student motivation and support services, institu tional infrastructure, confidence level in carrying out specific clinical procedures. We also referred to relevant literature like Golden standards of World Federation of Medical Education, the Association of American Medical College's 2000 graduation questionnaire ${ }^{7}$ and the Dundee Ready Education Environment (DREEM) inventory ${ }^{8}$ to refine our questions. The questionnaire was coded, and the data was analyzed for frequencies and percentages using SPSS version 16.

\section{RESULTS}

The questionnaire was distributed among 193 subjects. Out of those 93 participated in the study. Principal reasons for non-participation were: sickness leave, lack of time, and refusals. Our sample consisted of $79 \%$ females and $21 \%$ males. Table 1

Table: 1 Gender Distribution in three Dental Colleges

\begin{tabular}{|c|c|c|c|c|}
\hline Gender & $\begin{array}{c}\text { Khyber College of } \\
\text { Dentstry }\end{array}$ & $\begin{array}{c}\text { Sardar Begum Dental } \\
\text { College }\end{array}$ & $\begin{array}{c}\text { Peshawar Dental } \\
\text { College }\end{array}$ & Total \\
\hline Female & $73.5 \%$ & $72.2 \%$ & $100 \%$ & $79 \%$ \\
\hline Male & $26.4 \%$ & $28 \%$ & - & $21 \%$ \\
\hline
\end{tabular}


The results revealed an overall positive experience regarding academic curriculum. $\quad 74 \%$ agreed about adequate basic sciences and $26 \%$ did not agree.To a question regarding curriculum improving knowledge $48 \%$ agreed and $52 \%$ disagreed. $32 \%$ subjects agreed to a question about the curriculum improving logical thinking and $68 \%$ disagreed. $37 \%$ agreed and $63 \%$ d isagreed about the current academic in motivating the students to study. $39 \%$ agreed and $61 \%$ disagreed to a question on development of concepts. Majorit $y$ of the subjects $75 \%$ agreed to a question regarding current academics and its relevance to a career in healthcare and $25 \%$ disagreed.

(Table 2)

Table: 2. Opinions about the components of academic curriculum, percentage of respondents to each item

\begin{tabular}{|c|c|c|c|c|c|c|c|c|c|}
\hline \multirow[t]{2}{*}{ S .No } & \multirow[t]{2}{*}{ Attribute } & \multicolumn{2}{|c|}{$\begin{array}{l}\text { Peshawar Dental } \\
\text { College }\end{array}$} & \multicolumn{2}{|c|}{$\begin{array}{l}\text { Khyber College of } \\
\text { Dentistry }\end{array}$} & \multicolumn{2}{|c|}{$\begin{array}{l}\text { Sardar Begum Dental } \\
\text { College }\end{array}$} & \multicolumn{2}{|l|}{ Total } \\
\hline & & Agree & Disagree & Agree & Disagree & Agree & Disagree & Agree & Disagree \\
\hline 1 & $\begin{array}{l}\text { I received adequate basic } \\
\text { sciences that prepared me for } \\
\text { clinical practice }\end{array}$ & $20(86.9)$ & $3(13.1 \%)$ & $20(59 \%)$ & $14(41 \%)$ & $29(80.5 \%)$ & $7(19.5 \%)$ & $74 \%$ & $25 \%$ \\
\hline 2 & $\begin{array}{l}\text { You prefer integrated teaching to } \\
\text { traditional teaching }\end{array}$ & $18(78.2)$ & $5(21.8 \%)$ & $31(91 \%)$ & $3(9 \%)$ & $31(86 \%)$ & $5(14 \%)$ & $86 \%$ & $13 \%$ \\
\hline 3 & $\begin{array}{l}\text { Does the current curriculum } \\
\text { improves application of } \\
\text { Knowledge }\end{array}$ & $16(69 \%)$ & $7(31 \%)$ & $11(48 \%)$ & $23(52 \%)$ & $18(50 \%)$ & $18(50 \%)$ & $48 \%$ & $51 \%$ \\
\hline 4 & $\begin{array}{l}\text { The current curriculum creates } \\
\text { logical thinking }\end{array}$ & $9(39 \%)$ & $14(61 \%)$ & $8(23.5 \%)$ & $26(76 . \%)$ & $13(36 \%)$ & $23(64 \%)$ & $32 \%$ & $67 \%$ \\
\hline 5 & It motivates the students to study & $12(52 \%)$ & $11(48 \%)$ & $8(23.5 \%)$ & $26(76 . \%)$ & $15(41.6 \%)$ & $21(58 . \%)$ & $37 \%$ & $62 \%$ \\
\hline 6 & $\begin{array}{l}\text { It helps in development of } \\
\text { concepts }\end{array}$ & $13(56 \%)$ & $10(44 \%)$ & $11(32 \%)$ & $23(68 \%)$ & $13(36 \%)$ & $23(64 \%)$ & $39 \%$ & $60 \%$ \\
\hline 7 & $\begin{array}{l}\text { It helps to create Interest in } \\
\text { subjects }\end{array}$ & $10(43 \%)$ & $13(57 \%)$ & $8(23.5 \%)$ & $26(76 . \%)$ & $13(36 \%)$ & $23(64 \%)$ & $33 \%$ & $66 \%$ \\
\hline 8 & $\begin{array}{l}\text { It involves interaction and } \\
\text { participation by all }\end{array}$ & $10(43 \%)$ & $13(57 \%)$ & $5(15 \%)$ & $29(85 \%)$ & $11(30.5 \%)$ & $25(69 . \%)$ & $27 \%$ & $72 \%$ \\
\hline 9 & $\begin{array}{l}\text { It helps to boost the confidence } \\
\text { and speaking skills }\end{array}$ & $13(56 \%)$ & $10(44 \%)$ & $8(23.5 \%)$ & $26(76 . \%)$ & $10(27.7 \%)$ & $26(72 . \%)$ & $33 \%$ & $66 \%$ \\
\hline 10 & $\begin{array}{l}\text { I feel I am well prepared for my } \\
\text { profession }\end{array}$ & $16(69 \%)$ & $7(31 \%)$ & $12(35 \%)$ & 22 (65\%) & $17(47 \%)$ & $19(53 \%)$ & $48 \%$ & $51 \%$ \\
\hline 11 & $\begin{array}{l}\text { My current dental curriculum } \\
\text { helped me in the development of } \\
\text { Problem solving skills }\end{array}$ & $12(52 \%)$ & $11(48 \%)$ & $16(47 \%)$ & 18 (53\%) & $17(47 \%)$ & 19 (53\%) & $48 \%$ & $51 \%$ \\
\hline 12 & $\begin{array}{l}\text { Much of what I have learnt seems } \\
\text { relevant to a career in health } \\
\text { care }\end{array}$ & $19(82 \%)$ & $4(18 \%)$ & $24(70 \%)$ & $10(30 \%)$ & 27 (75\%) & $9(25 \%)$ & $75 \%$ & $24 \%$ \\
\hline
\end{tabular}

On analyzing the perceptions of student s on clinical curriculum $69 \%$ agreed and $31 \%$ disagreed about adequate clinical training. To a question about the amount of clinical materials provided, $51 \%$ agreed and $49 \%$ disagreed. $66 \%$ agreed and $34 \%$ disagreed about the duration clinical sessions provided to them. $64 \%$ agreed and $36 \%$ disagreed about a question regarding proficiency in clinical skills because of the opportunities to practice. Question regarding things moving too fast to learn anything $55 \%$ agreed and $45 \%$ disagreed. $53 \%$ subjects bel ieved of gaining sufficient experience in health promotion and preventive dentistry and $47 \%$ did not agree. (Table 3) 
Table: 3 Opinions about the components of Clinical curriculum, percentage of respondents to each item:

\begin{tabular}{|c|c|c|c|c|c|c|c|c|}
\hline \multirow{2}{*}{ Attibutes } & \multicolumn{2}{|c|}{ Peshawar Dental college } & \multicolumn{2}{|c|}{$\begin{array}{c}\text { Khyber College of } \\
\text { Dentstry }\end{array}$} & \multicolumn{2}{|c|}{$\begin{array}{c}\text { Sardar Begum Dental } \\
\text { College }\end{array}$} & \multicolumn{2}{|c|}{ Total } \\
\hline & Agree & Disagree & Agree & Disagree & Agree & Disagree & Agree & Disagree \\
\hline $\begin{array}{l}\text { I had adequate clinical training } \\
\text { under supervision of faculty }\end{array}$ & $18(78 \%)$ & $5(22 \%)$ & $21(62 \%)$ & $13(38 \%)$ & $26(72 \%)$ & $10(28 \%)$ & $69 \%$ & $30 \%$ \\
\hline $\begin{array}{l}\text { I am satsfied with clinical } \\
\text { materials provided to me }\end{array}$ & 9 (32\%) & $14(68 \%)$ & $18(53 \%)$ & $16(47 \%)$ & $21(58 \%)$ & $15(42 \%)$ & $52 \%$ & $48 \%$ \\
\hline $\begin{array}{l}\text { The number/duraton of clinical } \\
\text { sessions provided to me were } \\
\text { adequate }\end{array}$ & $18(78 \%)$ & $5(22 \%)$ & $18(53 \%)$ & $16(47 \%)$ & $26(72 \%)$ & $10(28 \%)$ & $66 \%$ & $33 \%$ \\
\hline $\begin{array}{l}\text { I became more proficient in } \\
\text { clinical skills because of } \\
\text { opportunities to practice a } \\
\text { receive feedback }\end{array}$ & $17(74 \%)$ & $6(26 \%)$ & $23(68 \%)$ & $11(32 \%)$ & $20(55 \%)$ & $16(45 \%)$ & $64 \%$ & $35 \%$ \\
\hline $\begin{array}{l}\text { Things moved too fast for me to } \\
\text { learn anything }\end{array}$ & $19(83 \%)$ & $4(17 \%)$ & $14(41 \%)$ & $20(59 \%)$ & $19(53 \%)$ & $17(47 \%)$ & $55 \%$ & $44 \%$ \\
\hline $\begin{array}{l}\text { I believe I have gained sufficient } \\
\text { experience in health promoton } \\
\text { and operati ve denttry }\end{array}$ & $13(56 \%)$ & $10(44 \%)$ & $18(53 \%)$ & $16(47 \%)$ & $19(53 \%$ & $17(47 \%)$ & $53 \%$ & $46 \%$ \\
\hline
\end{tabular}

The students' confidence level in carrying-out specific clinical procedures (Table 4) showed some areas where further training was required like Oral Radiography where $50 \%$ of Participants were not confident.

Table: 4. Confidence in carrying out specific clinical procedures, percentage of respondents to each item:

\begin{tabular}{|c|c|c|c|c|c|c|c|c|c|}
\hline \multirow{2}{*}{ S. No } & \multirow{2}{*}{ Attibutes } & \multicolumn{2}{|c|}{$\begin{array}{l}\text { Peshawar Dental } \\
\text { College }\end{array}$} & \multicolumn{2}{|c|}{$\begin{array}{l}\text { Khyber College of } \\
\text { Dentstry }\end{array}$} & \multicolumn{2}{|c|}{$\begin{array}{l}\text { Sardar Begum Dental } \\
\text { College }\end{array}$} & \multicolumn{2}{|l|}{ Total } \\
\hline & & Confident & $\begin{array}{l}\text { Not } \\
\text { confident }\end{array}$ & Confident & $\begin{array}{l}\text { Not } \\
\text { confident }\end{array}$ & Confident & $\begin{array}{l}\text { Not } \\
\text { confident }\end{array}$ & Confident & $\begin{array}{l}\text { Not } \\
\text { confident }\end{array}$ \\
\hline 1 & $\begin{array}{l}\text { Dental } \\
\text { extracti } n\end{array}$ & $22(96 \%)$ & $1(4 \%)$ & 31 (91\%) & $3(9 \%)$ & 31 (86\%) & 5 (14\%) & $90 \%$ & $.096 \%$ \\
\hline 2 & $\begin{array}{l}\text { Restoratve } \\
\text { care }\end{array}$ & 19 (83\%) & $4(17 \%)$ & 28 (82\%) & $6(18 \%)$ & 25 (69\%) & $11(31 \%)$ & $77 \%$ & $22 \%$ \\
\hline 3 & $\begin{array}{l}\text { Oral } \\
\text { diagnosis }\end{array}$ & 15 (65\%) & $8(35 \%)$ & $18(53 \%)$ & $16(47 \%)$ & 25 (69\%) & $11(31 \%)$ & $62 \%$ & $37 \%$ \\
\hline 4 & $\begin{array}{l}\text { Oral } \\
\text { radiography }\end{array}$ & $13(56 \%)$ & 10 (44\%) & $14(41 \%)$ & 20 (59\%) & 19 (53\%) & 17 (47\%) & $49 \%$ & $50 \%$ \\
\hline 5 & $\begin{array}{l}\text { Basic perio } \\
\text { care }\end{array}$ & 20 (87\%) & $3(13 \%)$ & $23(68 \%)$ & 11 (32\%) & $29(80 \%)$ & 7 (20\%) & $77 \%$ & $22 \%$ \\
\hline 6 & $\begin{array}{l}\text { Prosthetc } \\
\text { care }\end{array}$ & 14 (61\%) & $9(39 \%)$ & $19(56 \%)$ & 15 (44\%) & 27 (75\%) & 9 (25\%) & $64 \%$ & $35 \%$ \\
\hline 7 & $\begin{array}{l}\text { Educatng a } \\
\text { patent }\end{array}$ & 22 (96\%) & $1(4 \%)$ & 32 (94\%) & $2(6 \%)$ & $36(100 \%)$ & 0 & $96 \%$ & $.032 \%$ \\
\hline 8 & $\begin{array}{l}\text { Writng a } \\
\text { dental } \\
\text { prescripton }\end{array}$ & 16 (69\%) & 7 (31\%) & $25(73 \%)$ & $9(27 \%)$ & 22 (61\%) & $14(39 \%)$ & $67 \%$ & $32 \%$ \\
\hline
\end{tabular}




\section{DISCUSSION}

The perceptions of graduating dental students concerning the curriculum, motivation and support systems are very important. Their opinions on the teaching , learning programs, clinical experience, and perceived competence in carrying out common clinical procedures and confidence to open an independent dental practice are all so important. In this study our aim was to gain an insight about the student's perce ption of the current clinical and academic curriculum. Results of the questionnaire showed different dimensions of the learning environment in the institution. Though the results of one dental school may not be representative of all dental schools, therefo re in the present study all the three dental schools are included. Similar findings were noted by Vyaset al. ${ }^{9}$

Opinions about the components of learning experience in undergraduate curriculum showed an overall satisfaction with the teaching of basic sciences, the positive role of current curriculum in improving knowledge. The students mostly disagreed about the question regarding the role of curriculum in motivation of students, development of concepts, confidence and speaking skills. In the present study observation of the subjects regarding clinical curriculum showed a positive response regarding adequate clinical training and duration of clinical skills. Most of the students believe they have gained sufficient experience in the field of health promotion and can be an asset to the community afterwards. The students also mentioned that they required some time to adjust to the clinical set-up. Similar opinions were observed in other studies ${ }^{10,11,12}$. The confidence level of house officers carrying out thedental procedure was satisfactory although most of them believed oral radiology training could be improved.

Limitations of the study were that the student's perception alone may not be completely adequate to assess some aspects of the cur riculum. Since self-perceived competence often falls short of expected competence. Since our study was on student's perspective, we did not consider seeking the opinions of faculty, administrators, parents and patients.

\section{CONCLUSION}

The study helped us in identifying the strengths of current curriculum like improving knowledge, basic sciences, adequate clinical training, the duration of clinical skills in student's perspective. This study helped us to assess the clinical skills of all the house officers in performing different clinical procedures. A larger study with open ended questions is required as there is a need to conduct a more in -depth study to better investigate the curriculum involving other stake holders.

\section{REFERENCES}

1. Kern DE, Thomas PA, Hughes MT. Curriculum development for medical education: a six $\quad$-step approach. 2nd ed.Baltimore: John Hopkins University Press, 1998.

2. .Henzi $D$, Davis $E$, Jasinevicius $R$, Hendricson $W$. In the students' own words: what are the strengths and weaknessesof the dental school curriculum? J Dent Educ2007;71(5):632-45.

3. Arena G, Kruger E, Holley D, Millar S, Tennant M. Western Australian dental graduates' perception of preparedness to practice: a five-year follow-up. J Dent Educ2007;71(9):1217-22.

4. Cardall WR, Rowan RC, Bay C. Dental education from the students' perspective: curriculum and climate. J Dent Educ 2008;72(5):600 
5. KalpanaKumari M.K., Vijaya V., MysorekarSeema Raja. Student's perception about integrated teaching in an undergraduate medical curriculum. Journal of Clinical and Diagnostic Research 2011; 5:1256-1259.

6. .Lockwood JH, Danoff D, Whitcomb ME. The AAMC's 2000 graduation questionnaire. JAMA 2000;284(9):1080.

7. Varma R, Tiyagi E, Gupta JK. Determining the quality of educational climate acr oss multiple undergraduate teaching sites using the DREEM inventory. BMC Med Educ2005;5(1):8.

8. Akturk Z, Al-Megbil T. Evaluation of the learning environment for diploma in family medicine with the Dundee Ready Education Environment (DREEM) inventory. J Educ Eval Health Prof 2010;7:2.

9. Vyas R, Jacob M, Faith M, Isacc B, Rabi S, Satish Kumar S, Selvakumar D, Ganesh.A. An effective, integrated learning programme in the first year of the medical course. The National Medical Journal of India.2008; 21:1-6.

10. Students perception about integrated teaching in an under graduate medical curriculum ( Dr Prasad uma, Dr K kajani, Dr Prasad Usha) Indian journal of basic and applied medical research. March 2015 vol 4.

11. Yusof ZY, Jaafar N, Jallaludin RL, Abu-Hassan MI, RazaklA. Malaysian dental graduates' competence in holistic care: what do graduates and employers think? J Dent Educ2010;74(12):1380 7.

12. Razak IA, Latifah RR, Jaafar N, Abu Hassan MI, Ab Murat N. Assessing the competence of University of Malaya dental graduates: employers' and graduates' perceptions. J Dent Educ 2008;72(3):364-9.

LICENSE: JGMDS publishes its articles under a Creative Commons Attribution Non-Commercial Share-Alike license (CC-BY-NC-SA 4.0) COPYRIGHTS: Authors retain the rights without any restrictions to freely download, print, share and disseminate the article for any lawful purpose. It includes scholarly networks such as Research Gate, Google Scholar, LinkedIn, Academia.edu, Twitter, and other academic or professional networking sites. 